\title{
Malignant Type AB Thymoma
}

National Cancer Institute

\section{Source}

National Cancer Institute. Malignant Type AB Thymoma. NCI Thesaurus. Code C6886.

A type $A B$ thymoma which is characterized by an aggressive clinical course (capsular invasion, infiltration of the surrounding tissues) and can metastasize. 